\title{
RESENHA DE CASOS MAIS SIGNIFICATIVOS JULGADOS PELO SUPREMO TRIBUNAL FEDERAL NO ANO DE 2016
}

\section{Brazilian Supreme Court Case Law, the most important decisions}

\author{
PAULO GUSTAVO GONET BRANCO' \\ Instituto Brasiliense de Direito Público \\ pgbranco@gmail.com
}

Cómo citar/Citation

Gonet Branco, P. G. (2017).

Resenha de casos mais significativos julgados pelo Supremo Tribunal Federal no ano de 2016. Anuario Iberoamericano de Justicia Constitucional, 21, 211 -237. doi: https://doi.org/10.18042/cepc/aijc.21.09

\section{SUMARIO}

I. CRISE POLÍTICA: 1. Réu em processo penal não pode assumir a Presidência da República. 2. Nulidade de nomeações de Ministros de Estado. 3. O impeachment da Presidente da República. 4. Ordem de votação no procedimento do impeachment. Auto-contenção do Tribunal. II. FEDERALISMO. III. DIREITOS FUNDAMENTAIS: 1. Execução da pena e presunção de inocência. 2. Direitos sociais: 2. 1. Greve de servidores públicos. 2.2. Licença maternidade e adoção. 2.3. Direito à saúde e a pílula do câncer. 3. Direito à nacionalidade. 4. Direito à privacidade, sigilo bancário e acesso de dados pelo Fisco. 5. Liberdade de expressão e classificação de programas de televisão segundo adequação a faixas etárias distintas. 6. Liberdade de expressão, tatuagens e policial. 7. Liberdade religiosa e crítica a outras religiões. 8. Direito de propriedade e pena de confisco. 9. Direito à filiação e dignidade da pessoa. 10. Inviolabilidade de domicílio. IV. RESPONSABILIDADE CIVIL DO ESTADO POR MORTE DE PRESIDIÁRIO. V. SEPARAÇÃO DE PODERES E DEFENSORIA PÚBLICA. VI. VAQUEJADA E VETO A TRATAMENTO CRUEL DE ANIMAIS. VII. CONCLUSÃO.

1 Doutor em Direito (UnB). Professor de Direito Constitucional (graduação e mestrado) no Instituto Brasiliense de Direito Público - IDP e na Escola Superior do Ministério Público do Distrito Federal e Territórios. Membro do Ministério Público Federal. 
Mais uma vez, em 2016, tanto o número de processos que aportaram ao Supremo Tribunal Federal como o dos que receberam decisão supera a casa da centena de milhares. A longo do ano, foram julgados 117.093 processos; a grande maioria (102.564) resolvida por decisão do relator, e não por órgão colegiado (por uma das duas Turmas, composta por cinco Ministros, ou pelo Plenário, que reúne todos os onze integrantes da Corte). Essas decisões são denominadas monocráticas. Majoritariamente, afirmam a presença de algum obstáculo formal, de índole processual, à admissibilidade do instrumento empregado para provocar a jurisdição do Supremo Tribunal ou aplicam jurisprudência já assentada. Não são pronunciamentos, portanto, sobre matérias novas. Em não poucas vezes, o sucumbente se vale de mecanismos processuais para desafiar a decisão monocrática perante o órgão colegiado a que pertence o relator. Esses recursos raramente têm êxito, mas demandam reexame dos autos, custam esforço argumentativo e consomem tempo da Corte. Boa parte das 14.529 decisões colegiadas se refere a essas hipóteses. Quem acompanha as estatísticas do Supremo Tribunal Federal, portanto, ao ler que a Corte julgou no ano mais de cem mil processos, não deve ser levado ao equívoco de supor uma delirante criatividade no Brasil para inventar novos problemas jurídicos. O sistema processual de acesso ao Supremo Tribunal certamente que carece de melhoramentos e algumas medidas racionalizadoras vêm sendo implementados nos últimos dez anos. A situação já foi pior em termos de carga de trabalho e o viés atual é de progresso nesse aspecto. Nas próximas linhas, repasso alguns dos precedentes mais salientes no plano do interesse do estudioso de direito comparado.

\section{CRISE POLÍTICA}

Em 2012, o país se surpreendeu com os montantes multimilionários movimentados por esquemas grandiosos de corrupção, envolvendo empresários e integrantes de poderes políticos. No mais extenso julgamento da história do Supremo Tribunal, políticos graduados e agentes privados foram condenados a penas significativas. Em 2014, às vésperas de eleições gerais, começaram a surgir indícios de um quadro ainda mais aterrador de depravação administrativa. Uma gigantesca operação investigatória foi, aos poucos, revelando relações de empresas de grande porte com partidos e políticos, a envolver transferências irregulares de recursos bilionários. A operação investigatória, com o nome de lava-jato ${ }^{2}$,

2 Trata-se de corruptela de lava-a-jato. A denominação se deve ao tímido início da operação, consistente na investigação sobre negócios com moedas estrangeiras numa sala de um posto de abastecimento de gasolina e de lavagem de veículos. 
foi favorecida por um conjunto de depoimentos de pessoas que participaram de ilícitos e que buscaram os benefícios de colaboração premiada para expor à Polícia Federal e ao Ministério Público Federal um quadro de fatos estarrecedores sobre episódios de corrupção e lavagem de dinheiro.

À crise política somou-se a crise econômico-financeira, advinda do que se apontou como incúria administrativa convivendo com adversidades internacionais no mercado de commodities. A situação gerou comoção nacional, com milhões de pessoas acorrendo às ruas, para se insurgir contra os abusos que vinham sendo desnudados. Foi aberto processo de impeachment da Presidente da República. O procedimento é pouco claro, disposto sobretudo em diploma legal editado sob a vigência de Constituição antiga. Tampouco a Constituição em vigor desce a minúcias a esse respeito. De toda sorte, o processo de impeachment foi autorizado pela Câmara dos Deputados e o Senado julgou e impôs a pena de perda do cargo à Presidente da República.

O contexto social, marcado pelo azedume político, engendrou diversas polêmicas jurídicas. Várias questôes - muitas em torno das investigações da lava-jato - ainda pendem, em 2017, de deslinde; algumas foram resolvidas pelo Supremo Tribunal Federal já em 2016. Vale repassá-las.

\section{RÉU EM PROCESSO PENAL NÃO PODE ASSUMIR A PRESIDÊNCIA DA REPÚBLICA}

As circunstâncias ligadas ao processo de impeachment, provocaram questôes relacionadas com a perspectiva da queda da titular da Presidência.

Quer para os casos de vacância temporária (uma viagem internacional do Presidente da República, por exemplo), quer para os de impedimento definitivo, a Constituição Federal prevê linha sucessória para o cargo de Presidente da República, que se inicia com o Vice-Presidente, seguido pelo Presidente da Câmara dos Deputados (casa dos representantes do povo), pelo Presidente do Senado (casa dos representantes dos Estados-membros), chegando, por último, ao Presidente do Supremo Tribunal Federal (arts. 79 e 80). Pôs-se a questão de saber, no caso de tanto o Presidente como o Vice-Presidente da República serem impedidos, ou se apenas aquele o sendo e o Vice necessitar se ausentar temporariamente do Território Nacional, quais as consequências para a cadeia sucessória de os Presidentes das Casas do Congresso Nacional se tornarem réus em ação penal.

O tema era premente, porquanto o Supremo Tribunal acabara por receber denúncia contra o Presidente da Câmara. Um partido político ajuizou arguição de descumprimento de preceito fundamental, requerendo que a Corte declarasse que, quem fosse réu em processo penal (vale dizer, tivesse denúncia contra si recebida), não poderia exercer o cargo constante da linha 
de sucessão presidencial. $\mathrm{O}$ argumento, a par de invocação de motivos éticos, salientava que o próprio Presidente da República, quando vê recebida denúncia contra si, é afastado do cargo, nos termos do art. $86, \mathbb{} 1^{\circ}$, I e $\$ 2^{\circ}$, da Constituição.

Quando foi aberto processo penal contra o Presidente do Senado no STF, em $1^{\circ} .12 .2016$ (Inq 2.593), o Partido requerente da ADPF acrescentou à inicial pedido de medida cautelar para que o titular do cargo fosse dele afastado. $\mathrm{O}$ relator acedeu ao requerimento monocraticamente. O Senado, porém, não cumpriu a determinação, ao argumento de que aguardava um deliberação do Plenário do STF. A decisão do colegiado veio no dia 6 de dezembro. O Tribunal não manteve o afastamento do parlamentar da Presidência da Casa Legislativa, mas ficou assentado que ele não poderia assumir, mesmo que transitoriamente, a Presidência da República.

A questão não encontra solução direta no texto da Carta da República, daí a dificuldade inicial do seu desate. Para enfrentá-la, o Tribunal considerou que a providência da suspensão do cargo a que Presidente tornado réu se sujeita tem em mira preservar a «respeitabilidade das instituiçôes republicanas». Extraiu daí que os sucessores do Presidente que estejam respondendo a ação penal, pela mesma razão, não poderiam assumir o cargo. Seria contraditório que recebêssem um tratamento mais favorecido do que é atribuído ao titular eleito. De outro lado, como a Constituição não estabelece a incompatibilidade dos cargos de Presidente da Câmara dos Deputados e do Senado Federal com a condição de denunciado por crime, não seria correto afastar quem estivesse nessa contingênica do posto no Poder Legislativo. A solução encontrada foi a de estabelecer que a linha sucessória sofreria salto no que tange a qualquer dos seus integrantes quando estiver respondendo a processo por ilícito penal.

\section{NULIDADE DE NOMEAÇÕES DE MINISTROS DE ESTADO}

No caldo da crise política que atravessou o ano de 2016, houve também dois episódios de deliberações na Suprema Corte em demandas que impugnavam a nomeação pela ainda Presidente da República de Ministros de Estado.

Em março, a Presidente nomeou um Procurador de Justiça estadual para o cargo de Ministro da Justiça. Ocorre que a Constituição impede que integrante do Ministério Público ocupe cargo fora da estrutura da carreira. ${ }^{3}$ A nomeação, entretanto, buscava amparo em uma resolução de 2011, do

3 Estão ressalvados os membros do Ministério Público Federal que ingressaram na carreira antes de 1988, por força de dispositivo específico do Ato das Disposições Constitucionais Transitórias, que está inserido na Constituição de 1988. 
Conselho Nacional do Ministério Público, que estimara controvertida a interpretação da norma relevante da Constituição, tendo por isso revogado ato normativo anterior que vedava expressamente a atuação estranha aos quadros da instituiçãa.

Um partido político ajuizou arguição de descumprimento de preceito fundamental, atacando tanto a resolução como o ato de nomeação em si mesmo. O julgamento da ADPF 388 se deu em 9.3.2016.

Uma primeira questão de ordem processual foi resolvida, no que diz com o cabimento da ADPF. O Tribunal entendeu que o veto a que o membro do Ministério Público exerça cargo fora da carreira tem conexão com o princípio da separação dos poderes; nomeadamente, com a independência do parquet, compondo, assim, o domínio dos preceitos fundamentais da Carta aptos a servirem de parâmetro de controle por meio da ação ajuizada.

Embora a arguição de descumprimento de preceito fundamental instaure um processo de índole objetiva, foi admitido que se voltasse contra fatos concretos, podendo, portanto, servir de instrumento de controle não apenas de atos normativos. A Corte noticiou que 22 membros de vários ramos do Ministério Público achavam-se exercendo cargos no Executivo. O acórdão viu configurada, aí, uma institucionalização de uma prática contrária à Constituição e salientou que a ação também atacava diretamente ato concreto da Presidente da Republica. Nessas circunstâncias, afirmou cabível o ajuizamento da arguição de descumprimento de preceito fundamental.

O precedente, neste ponto, é relevante também do ponto de vista da compreensão dos instrumentos de controle direto de constitucionalidade no Brasil. Embora os demais meios, como a ação direta de inconstitucionalidade e a ação declaratória de constitucionalidade, visem invariavelmente a fiscalizar a integridade constitucional de atos normativos, admitiu-se, na ADPF 388, que ato concreto, em especial quando participa de uma multiplicidade deles, também possa ser diretamente confrontado com a Constituição Federal pelo STF. O acervo de jurisprudência da Corte já registrava precedente de linha análoga. Na ADPF 101, julgada em 11.3.2009, a demanda se dirigia contra "decisóes judiciais que autorizam a importação de pneus usados». Apontava-se que essas decisóes feriam portarias e decretos de órgãos federais, que expressamente proibiam esse comércio com o exterior. Dizia-se que essas decisóes, por isso, feriam normas da Constituição que cometem ao Executivo a composição de políticas públicas de proteção à saúde (art. 196) e ao meio ambiente (art. 225). A ADPF 101 foi admitida e julgada procedente.

Quanto ao mérito da ADPF contra a nomeação de membro do Ministério Público estadual como Ministro da Justiça, o STF reiterou entendimento 
antigo. Enfatizou que «é central ao regime de vedações dos membros do MP o impedimento ao exercício de cargos fora do âmbito da Instituição».

Ficou dito que o rol das atribuições do Ministério Público, disposto no art. 129 da Carta, não é exaustivo, podendo ser dilatado por lei, desde que as tarefas sejam compatíveis com as incumbências constitucionais do parquet, enumeradas no caput do art. 127 («defesa da ordem pública, do regime democrático e dos interesses sociais e individuais indisponíveis») ${ }^{4}$. O Tribunal chamou atenção para o fato de que, nessas circunstâncias, o membro do Ministério Público atua no desempenho das suas funções institucionais, o que não ocorre quando se afasta da carreira para atuar em cargo ou função do Executivo.

$\mathrm{O}$ argumento de que a assunção do cargo no Executivo seria admissível quando o Promotor Público estivesse licenciado da carreira foi desautorizado, com apelo aos termos da Constituição, vedatórios do exercício de outra função pública até mesmo nos casos de afastamento mais radical, como é a hipótese da disponibilidade.

Ao fim, foi determinado que todos os membros de Ministério Público na situação descrita como irregular fossem exonerados do cargo temporário —inclusive o Ministro da Justiça—. A Resolução do CNMP de 2011 também foi declarada inconstitucional.

Em outro episódio, foram impetrados mandados de segurança (MS 34.070 e MS 34.701), impugnando a nomeação pela ainda Presidente da República, em março de 2016, do seu antecessor no Palácio do Planalto5, Luiz Inácio Lula da Silva, para o cargo de Ministro da Casa Civil. O ato fora atacado, porque associado à finalidade de conferir foro privilegiado ao ex-Presidente, livrando-o do juiz de primeira instância com atribuiçôes exclusivas para atuar na operação lava-jato, que vinha decretando prisões cautelares de diversos investigados. $\mathrm{O}$ relator dos processos enxergou nulidade na nomeação por desvio de finalidade e concedeu a liminar requerida para obstar a posse. Mais adiante, a Presidência da República houve por bem exonerar

4 Foram citados exemplos, como o da Lei 12.529/2011, que prevê a atuação do Ministério Público perante o Conselho Administrativo de Defesa Econômica - CADE e o do art. 178 do Código de Processo Civil, que chama o parquet a atuar como custos legis nos processos que envolvam interesse público ou social, interesse de incapaz ou litígios coletivos pela posse de terra rural ou urbana.

5 Sede do Executivo Federal em Brasília. 
o indicado e os mandados de segurança perderam objeto, não tendo o seu mérito conhecido.

No final de 2015, ainda, o Procurador-Geral da República requereu o afastamento cautelar do Presidente da Câmara dos Deputados tanto do seu cargo de Deputado como do de Presidente da Casa legislativa (AC 4.070). O relator concedeu a liminar na manhã do dia 5 de maio. À tarde, o Plenário referendou a medida. O Presidente afastado era réu em ação penal em curso no STF por crime comum. O Tribunal reconheceu que a situação era de «franca excepcionalidade», concordou com a decisão do relator, tendo em vista a "comprovação, na hipótese, da presença de múltiplos elementos de riscos para a efetividade da jurisdição criminal e para a dignidade da própria casa legislativa».

\section{O IMPEACHMENT DA PRESIDENTE DA REPÚBLICA}

Não obstante todos esses acontecimentos denotarem, por si, a magnitude da crise política que marcou o ano, o evento de maior impacto foi o da aprovação do impeachment da Presidente da República, em 31 de agosto, pela expressiva votação no Senado de 61 votos favoráveis contra 20 Senadores que rejeitavam a denúncia apresentada por crime de responsabilidade.

O Presidente da República não pode sofrer ação penal, enquanto estiver no desempenho do seu mandato, a não ser em caso de crime cometido em razão das suas funções. Esse privilégio é conferido pelo art. $86, \$ 4^{\circ}$, da Constituição, e institui a chamada irresponsabilidade penal relativa do Presidente da República. Uma das hipóteses em que o Presidente da República se submete a denúncia por crime diz respeito aos crimes de responsabilidade, que estão definidos na própria Constituição (art. 85) e na Lei no 1.079/1950. Esses crimes de responsabilidade não correspondem às típicas sançôes penais (multa e privação de liberdade), mas atraem sanções político-administrativas (perda do cargo e inabilitação para o exercício de função pública por oito anos).

O pedido de impedimento do Chefe do Executivo pode ser deduzido por qualquer cidadão e deve ser dirigido à Câmara dos Deputados. Reconhece-se ao Presidente da Casa o poder de arquivar monocraticamente a acusação (cf. MS 30.672 AgR, DJe 17.10.2011 ${ }^{6}$ ) ou deliberar pelo seu prosseguimento, hipótese esta de raríssima ocorrência.

6 Lê-se na ementa do julgado: «Na linha da jurisprudência firmada pelo Plenário desta Corte, a competência do Presidente da Câmara dos Deputados e da Mesa do Senado Federal para recebimento, ou não, de denúncia no processo de impeachment não se restringe a uma admissão meramente burocrática, cabendo-lhes, inclusive, a faculdade 
No caso de 2016, o Presidente da Câmara deu seguimento a pedido de impeachment formulado por três juristas de renome, que acusavam a Presidente da República de editar decretos abrindo créditos suplementares em desacordo com a lei orçamentária.

Como era de se esperar, diversas questôes jurídicas procedimentais surgiram e o Supremo Tribunal foi chamado a enfrentá-las em arguição de descumprimento de preceito fundamental ajuizada por partido governista. A decisão na ADPF MC 378 foi publicada em 8 de março de 2016.

Do ponto de vista técnico, o acórdão é importante, porque acresce mais um traço definidor desse instrumento de ação direta perante o Supremo. A ação proposta pretendia que se declarasse a incompatibilidade de regras da lei de 1950 com a Constituição de 1988 e ainda que se suprissem omissões parciais na regulação do assunto. Envolvia, portanto, exame de omissão e, simultaneamente, de revogação de lei por Constituição posterior. Nenhum outro instrumento de processo objetivo poderia abranger essas pretensôes conjuntamente, a não ser a arguição de descumprimento de preceito fundamental. $\mathrm{O}$ Tribunal entendeu, por isso, que a ADPF era o instrumento adequado no caso, «tendo em vista que somente a apreciação cumulativa de tais pedidos é capaz de assegurar o amplo esclarecimento do rito do impeachment por parte do STF».

O processo de impeachment desdobra-se na Câmara e no Senado. O STF esclareceu que naquela é proferido um «juízo eminentemente político sobre os fatos narrados», com vistas a se dar seguimento ou a se rejeitar o processo. $\mathrm{O}$ juízo positivo sobre essa condição de procedibilidade deve reunir uma maioria de 2/3 dos Deputados Federais. Não há exigência mais acentuada de defesa técnica nessa fase, dada a natureza preliminar do exame submetido à Câmara dos Deputados, mas é dado ao acusado apresentar a sua defesa, antes da deliberação do Plenário, num prazo de dez sessōes.

Justamente porque não cabe à Câmara dos Deputados o processamento e o julgamento do Presidente da República, mas apenas a avaliação política do encaminhamento do pedido para o Senado —órgão que processa e julga—, o STF, em outro julgado, não viu

Ofensa à ampla defesa e ao contraditório, consubstanciadas na ausência de notificação da denunciada sobre a realização de esclarecimentos acerca da denúncia e posterior indeferimento de pedido de reabertura de prazo para a manifestação da defesa, juntada de documento estranho ao objeto da denúncia e ausência de mani-

de rejeitá-la, de plano, acaso entendam ser patentemente inepta ou despida de justa causa». 
festação do Procurador da impetrante na sessão de leitura do relatório na Comissão Especial. Isso porque, nessa fase ainda não há acusado ou litigante. (MS $34130 \mathrm{MC}$, DJe 1.9.2016)

Admitido o processo na Câmara, segue a fase do Senado. Ali, haverá uma primeira votação, em seguida a parecer elaborado por uma comissão especial. O Plenário do Senado decide, em primeiro lugar, se concorda com o início do julgamento. Assim, não cabe ao Presidente dessa Casa rejeitar monocraticamente a denúncia, como pode fazer o seu homólogo da Câmara. Essa decisão se toma por maioria simples.

Todas as votações no processo de impeachment, inclusive aquelas para formação de Comissão Especial, devem sem abertas, i.é, com identificação dos votantes. Segundo o STF, visa-se, assim, "permitir maior transparência, controle dos representantes e legitimação do processo».

Se não há defesa prévia antes de o Presidente da Câmara dar seguimento à denúncia, no Senado o acusado pode, querendo, manifestar-se antes de a acusação ser apreciada em qualquer dos dois momentos em que isso ocorre.

Ademais, embora os Senadores atuem como juízes, assentou-se que não se aplicam a eles os casos de suspeição e impedimento indicados no Código de Processo Penal. Disse o STF:

A diferença de disciplina se justifica, de todo modo, pela distinção entre magistrados, dos quais se deve exigir plena imparcialidade, e parlamentares, que podem exercer suas funçōes, inclusive de fiscalização e julgamento, com base em suas convicçōes político-partidárias, devendo buscar realizar a vontade dos representados.

O interrogatório do Presidente da República é o último ato de instrução do processo.

$\mathrm{Na}$ ADPF, o Tribunal terminou por converter o julgamento da medida cautelar em definitivo, a bem da segurança jurídica.

\section{ORDEM DE VOTAÇÃO NO PROCEDIMENTO DO IMPEACHMENT. AUTO-CONTENÇÃO DO TRIBUNAL}

Ainda sobre o procedimento do impeachment, o Supremo Tribunal Federal se recusou a rejeitar a aplicação de norma do Regimento Interno da Câmara dos Deputados sobre a ordem da votação dos Deputados. A Corte entendeu que a Constituição silenciara a esse respeito e não viu afronta ao princípio do devido processo legal na disposição prevendo que os votos seriam colhidos alternadamente conforme o Estado-membro se situasse no Norte ou no Sul 
do país. Afirmou que não cabia ao Supremo Tribunal impor uma sequência diferente, como a da ordem alfabética, preconizada pelo autor. A Corte disse:

Interferências recíprocas nas manifestações dos julgadores são inevitáveis em qualquer ordem de votação nominal, seja qual for o critério de sequenciamento adotado, não sendo possível presumir a ilegitimidade da deliberação do colegiado parlamentar, por mera alegação de direcionamento, em um ou outro sentido. A Constituição Federal não estabelece ordem de votação nominal que possa ter sido afrontada pela norma regimental atacada. Ausência de demonstração das lesôes constitucionais deduzidas.

ADI 5498 MC, Tribunal Pleno, julgado em 14/04/2016)

\section{FEDERALISMO}

Se é possível enxergar na crise política raízes em incúria administrativa salientada por crise econômica ligada à queda dos preços de commodities no mercado externo, não causará surpresa adiantar que o quadro de difícil governabilidade federal também se reproduziu no âmbito dos Estados-membros. $\mathrm{O}$ cenário de desajuste fiscal na maior parte deles atingiu níveis de inaudita dramaticidade, a ponto de, em alguns, não haver recursos para o pagamento do próprio funcionalismo público, para o custeio da segurança pública e para o atendimento dos aposentados. O STF foi chamado, uma vez mais, a intervir, o que fez incentivando, precipuamente, a autocomposição das partes.

Alguns Estados ajuizaram mandados de segurança com vistas a reduzir o montante das suas dívidas para com o governo central. Foram concedidas liminares para onze Estados-membros, ${ }^{7}$ excluindo das suas dívidas a incidência de juros compostos. Em 27 de abril, o Plenário, ao iniciar a apreciação em conjunto dos mandados de segurança, deliberou suspender todos os julgamentos por 60 dias, com vistas a incentivar a União e os Estados-membros a encontrarem uma solução negociada - o que acabou ocorrendo, com a celebração de acordo que alongou o prazo da dívida e fixou um prazo de carência de 4 anos para o pagamento do seu principal.

Outra disputa entre a União e os Estados-membros foi resolvida após a judicialização do tema. Em 2016, foi aprovada lei que facilitava a repatriação de recursos financeiros mantidos no exterior, com alta expectativa de ingressos no Tesouro Nacional. A repatriação previa incidência de multa sobre

$7 \quad$ MS 34.123, 34132, 34.141, 34.143, 34.151, 34.154, 34.168, 34.186, e também na ACO 2.925 e na Pet 6.398 . 
o imposto de renda devido. A União não cogitou de dividir os recursos da penalidade tributária com os Estados-membros, entendendo que não comporiam o montante das receitas que o governo central deve, constitucionalmente, partilhar com as entidades federadas. Uma integrante do Supremo Tribunal concedeu liminares em açōes cíveis originárias ${ }^{8}$, ordenando que a União depositasse em juízo a cota-parte dos Estados. Mais adiante, rodada de negociação política resultou na edição da Medida Provisória no 753 , que atendeu a reivindicação dos Estados-membros.

Em outro precedente, julgado em 17.11.2016, sob a sistemática da repercussão geral (RE 705.423-RG), o Plenário discutiu se os Municípios podem reclamar uma indenização da União, para compensar a perda da expectativa de participação de tributos federais — cujas receitas devem ser divididas com as entidades locais-, à conta de isenções e benefícios concedidos pelo governo federal.

A Constituição, no art. 159 , I, determina que $24,5 \%$ da arrecadação do imposto de renda e do imposto sobre produtos industrializados devem ser entregues ao Fundo de Participação dos Municípios, de onde o dinheiro é depois repassado a cada uma dessas pessoas jurídicas de direito público. Com objetivos de política fiscal, muitas vezes a União concede incentivos que se traduzem em reduções ou mesmo em isenção desses impostos. Isso, obviamente, gera impacto sobre o montante arrecadado e, em consequência, sobre a quantia a ser entregue ao Fundo. Por isso, um Município ajuizou ação contra a União, requerendo ser indenizado por esses favores que o prejudicaram. A causa chegou ao Plenário da Corte, para quem, sendo regular a concessão de incentivos, benefícios e isenções dos impostos pela União, o Município não tem por que se rebelar; afinal, quem tem a competência para tributar também possui a de isentar. A Corte assinalou que os Municípios não têm o direito de exigir que a União obtenha a arrecadação potencial máxima dos tributos. A União deve ao Fundo o percentual definido constitucionalmente da arrecadação efetiva —e não potencial— desses impostos.

Os recursos do Fundo são de especial relevância para a vida financeira dos Municípios, que se sustentam nessas quantias e nas auferidas por impostos de sua competência tributária. Entre os mais de 5.500 Municípios brasileiros, muitos são os que contam com reduzida capacidade de gerar e circular riquezas, o que os torna especialmente dependentes dos repasses de receitas federais. A decisão resolveu importante questão para o chamado federalismo fiscal brasileiro.

8 ACO 2.934, 2.935, 2.936, 2.938, 2.940, 2.941 e 2.942 de 11.11.2016. 


\section{DIREITOS FUNDAMENTAIS}

No campo dos direitos fundamentais o profícuo ano de 2016 também rendeu decisões dignas de nota. Uma delas não pode ser compreendida sem a conexão com os acontecimentos e expectativas relacionados com a operação lava-jato. Trata-se da decisão sobre o momento em que a presunção de inocência cessa, para fins de cumprimento de decisão penal condenatória.

\section{EXECUÇÃO DA PENA E PRESUNÇÃO DE INOCÊNCIA}

A Constituição de 1988 trata da presunção de inocência de modo bastante a favorável ao acusado, buscando o contraponto a abusos temidos e sofridos no regime que antecedeu à Carta. O inciso LVII do art. $5^{\circ}$ do Diploma estabelece que "ninguém será considerado culpado até o trânsito em julgado de sentença penal condenatória».

Logo em seguida ao advento da Constituição, apesar do dispositivo, o Supremo Tribunal entendia que, como o recurso extraordinário e o recurso especial — cabíveis de decisôes condenatórias proferidas na última instância ordinária- produziam efeitos meramente devolutivos (não suspendendo a eficácia, mesmo que provisória, dos julgados). O condenado em segunda instância já poderia iniciar o cumprimento da pena, ainda que recurso de índole extraordinária estivesse pendente de análise; afinal, nesses recursos, as questões de prova não são mais admissíveis e a determinação da culpa já estaria suficientemente alicerçada.

Em 5 de fevereiro de 2009, contudo, o STF revolucionou essa antiga inteligência, ao conceder ordem de habeas corpus no HC 84.078. Afirmou que, enquanto não transitasse em julgado a decisão condenatória — vale dizer, enquanto pendente qualquer recurso contra ela— não era possível exigir do réu o cumprimento da pena. $O$ réu poderia ser preso por alguns dos motivos ensejadores da prisão cautelar, mas não a título de cumprimento provisório da sanção - e isso porque, nesse ínterim, ainda operaria a presunção de que é inocente, em virtude dos termos do art. $5^{\circ}$, LVII, da Constituição.

A decisão motivou críticas, especialmente porquanto ensejou que as defesas mais tecnicamente competentes adiassem, em muito, o cumprimento das penas, ensejando prescrição e impunidade.

Sete anos passados, o Supremo Tribunal Federal retornou à sua primeira jurisprudência. Em 17 de fevereiro de 2016 o Plenário novamente abordou o assunto no HC 126.292. O entendimento voltou a ser o de que, mesmo não havendo o trânsito em julgado, a partir da última decisão das instâncias ordinárias, não caberia mais apreciar provas, e a presunção de inocência observada em grau máximo até ali, cederia à necessidade de se assegurar a efetividade da 
jurisdição criminal. O cumprimento provisório da pena não atentaria contra o núcleo essencial da garantia da não culpabilidade. Um dos votos que se uniram a essa inteligência afirmou que, «em país nenhum do mundo, depois de observado o duplo grau de jurisdição, a execução de uma condenação fica suspensa aguardando referendo da Suprema Corte».

A decisão foi tomada por uma maioria apertada. A corrente vitoriosa teve um voto a mais do que a que sustentava a posição de 2009. Não pode ser desprezada a circunstância histórica do ano da mais recente deliberação. Em 2016, houve uma sucessão nunca vista de prisões preventivas de empresários do mais alto coturno do país e de sanções penais de vários anos de reclusão. A possibilidade de protrair o cumprimento dessas penas para depois do trânsito em julgado das sentenças era vista como um fator de desprestígio da Justiça ante o maior escândalo de corrupção da República, exaustivamente relatado na imprensa. A decisão do STF mostrou a indisposição do Tribunal em ser brando e aproximou a prisão definitiva para tantos empresários e políticos enquadrados nas apurações do Ministério Público Federal e da Polícia Federal. Várias colaboraçõos premiadas, além disso, ocorreram depois de assentada a nova jurisprudência do Tribunal.

A decisão foi tomada em controle incidental. Logo após a decisão no habeas corpus, um partido político e o Conselho Federal da Ordem dos Advogados do Brasil ajuizaram duas ações declaratórias de constitucionalidade (ADC 43 e 44). Argumentaram que, em 2011, o Código de Processo Penal foi modificado para albergar artigo no mesmo sentido da anterior jurisprudência do STF. O artigo do CPP determina:

Art. 283. Ninguém poderá ser preso senão em flagrante delito ou por ordem escrita e fundamentada da autoridade judiciária competente, em decorrência de sentença condenatória transitada em julgado ou, no curso da investigação ou do processo, em virtude de prisão temporária ou prisão preventiva.

O Tribunal entendeu que a sua nova inteligência não conflitava com o dispositivo. Valeu-se da interpretação conforme à Constituição para concluir que a norma não exclui a prisão para cumprimento de pena fixada na última instância ordinária. A decisão foi tomada em julgamento de medida cautelar em 5 de outubro de 2016.

Um mês depois, o Plenário Virtual do STF tornou ao tema, ao apreciar o ARE 964.246 no regime da repercussão geral. Escreveu a tese de que:

A execução provisória de acórdão penal condenatório proferido em grau recursal, ainda que sujeito a recurso especial ou extraordinário, não compromete o princípio 
constitucional da presunção de inocência afirmado pelo artigo $5^{\circ}$, inciso LVII, da Constituição Federal.

\section{DIREITOS SOCIAIS}

O tema dos direitos sociais sempre empolga algumas discussões levadas à Corte. No ano em tela, entre outros, voltou à baila o direito de greve de servidores públicos, que segue sendo regido pela sistemática jurídica da greve no setor privado, à falta de edição de lei específica.

\subsection{Greve de servidores públicos}

No RE 693.456, julgado em 27.10.2016, com os efeitos além-partes das decisões proferidas em sede de repercussão geral, o Tribunal deliberou que a Administração Pública está obrigada a descontar da remuneração dos servidores que aderem ao movimento paredista os dias em que não houve serviço. Esse abatimento somente se torna indevido se a greve é resposta a ato ilegal do poder público, como a falta de pagamento dos salários. O máximo que se admite em favor dos grevistas é a substituição do corte do ponto por compensação na jornada de trabalho, havendo acordo para isso. Foi redigida a seguinte tese:

A administração pública deve proceder ao desconto dos dias de paralisação decorrentes do exercício do direito de greve pelos servidores públicos, em virtude da suspensão do vínculo funcional que dela decorre, permitida a compensação em caso de acordo. O desconto será, contudo, incabível se ficar demonstrado que a greve foi provocada por conduta ilícita do Poder Público.

\subsection{Licença maternidade e adoção}

$\mathrm{Na}$ lista de direitos sociais fundamentais do art. $7^{\circ}$ da Constituição, consta, no inciso XVIII, a «licença à gestante, sem prejuízo do emprego e do salário, com a duração de 120 dias».

A matéria é objeto também de legislação ordinária. Para os servidores civis da União, a lei coincide com a marca constitucional, no que tange às mães que deram filho à luz. Mas, em se tratando de adoção ou de guarda de menor a duração da licença é outra. Se a criança tem até um ano de idade, a licença é de 90 dias. Se tem mais do que isso, de 30 dias (art. 210 da Lei $n^{\circ} 8.112 / 90$ ). No RE 778.889 (DJe $1^{\circ} .8 .2016$ ), julgado com os efeitos das repercussão geral, a constitucionalidade da norma foi desafiada. A Corte, com argumentos centrados na isonomia e na proporcionalidade, deu a diferenciação por imprópria. Foi fixada esta tese: 
Os prazos da licença adotante não podem ser inferiores aos prazos da licença gestante, o mesmo valendo para as respectivas prorrogaçôes. Em relação à licença adotante, não é possível fixar prazos diversos em função da idade da criança adotada.

$\mathrm{Na}$ fundamentação, o Tribunal apoiou-se no art. $227, \mathbb{S} 6^{\circ}$, da Constituição, que determina que os filhos biológicos e adotivos hão de ter os mesmos direitos. Salientou que as crianças adotadas, segundo a experiência indica, podem exigir dos pais que as acolhem mais cuidados até do que os filhos gerados, dados os casos frequentes de traumas de toda ordem e de carências variadas que as acompanham. Daí o STF ter entendido que a diferenciação era arbitrária e desproporcionada. O relator mencionou uma «dívida moral do Estado para com menores vítimas da inepta política estatal de institucionalização precoce» e proclamou que deve haver compensação ao «ônus assumido pelas famílias adotantes, que devem ser encorajadas». Ficou garantida a todas as adotantes a licença igual à da gestante.

A decisão não esconde o efeito de corrigir o legislador. É significativa para exemplificar hipótese de deliberação manipulativa modificativa.

Do ponto de vista humanitário, o acórdão certamente motiva aplausos. Do ponto de vista técnico, provoca alguma perplexidade. A Constituição fala em licença para gestante e não para adotante, abrindo, quanto a esta última, liberdade de disciplina para o legislador. A licença à gestante, ademais, está prevista como um direito social do trabalhador; trata-se de um direito da mulher e, não diretamente do recém nascido; daí a estranheza ao caso do artigo da Constituição que proíbe tratamento discriminatório no que tange a direitos de que sejam titulares filhos legítimos e filhos adotados. Por último, está claro que o Tribunal criou vantagem, com repercussōes financeiras, para servidores públicos em substituição às que a lei previra. A decisão enfrenta a jurisprudência firme da Corte, no sentido de que vantagens assim estão submetidas à reserva de lei em sentido formal, i.e. à reserva de parlamento.

\subsection{Direito à saúde e a pílula do câncer}

Um professor de conceituada universidade pública em São Paulo desenvolveu uma pílula sintetizando a substância denominada fosfoetalomina. A pílula teria propaladas virtudes terapêuticas contra o câncer, inclusive de cura. O composto vinha sendo, por vários anos, distribuído gratuitamente a quem se interessasse, até que um ato da universidade proibiu a sua entrega, uma vez que não tinha o abono do órgão federal de vigilância sanitária. Houve protestos nos meios de comunicação e, especialmente, nas redes sociais. Várias ações judiciais foram propostas para que a proibição fosse suspensa. Uma lei do Congresso Nacional veio a ser aprovada em 2016 (Lei no 13.269), permitindo 
«a produção, manufatura, importação, distribuição, prescrição, dispensação, posse ou uso da fosfoetalomina sintética». A lei dispensava, literalmente, em caráter excepcional, a necessidade de registro sanitário, enquanto estivessem em curso estudos clínicos da substância.

$\mathrm{Na}$ ADI $5501 \mathrm{MC}$, julgada em 19 de maio de 2016, a Corte afirmou que o Poder Público tem o dever de zelar pela qualidade e segurança dos medicamentos. Apontou que, sem o registro no órgão sanitário, a presunção é a de que o produto é inadequado para a saúde humana e que essas análises técnicas incumbem à Administração, e não ao legislador. A lei teria violado o direito à saúde (art. 196 da Constituição) e também o princípio da separação dos poderes.

\section{DIREITO À NACIONALIDADE}

O Brasil adota essencialmente o critério do jus soli para definir os seus nacionais, embora o critério do sangue seja relevante em algumas situações previstas na Carta de 1988. A ordem constitucional, ademais, não é avessa a que o brasileiro possua mais de uma nacionalidade originária, mas prevê que a aquisição voluntária de outra nacionalidade conduz à perda da brasileira, salvo em hipóteses de se tratar de exigência por parte do país estrangeiro para que o indivíduo possa gozar de direitos civis (art. 12, $\$ 4^{\circ}$, II). Afinal, no rol dos direitos e garantias fundamentais, assegura-se ao brasileiro nato não ser extraditado (art. $5^{\circ}, \mathrm{LI}$ ).

A impetrante do MS 33.864, julgado em 19.4.2016, era brasileira nata, quando na década de 1990 foi morar nos Estados Unidos. Lá se casou com um norte-americano e obteve o green card. Em seguida naturalizou-se, divorciou-se e se casou com outro americano, do qual veio a ser acusada de havê-lo matado. Voltou para o Brasil e o governo dos EUA formulou pedido de extradição. O Ministério da Justiça abriu processo administrativo para a declaração da perda da nacionalidade, o que acabou por acontecer. Estava, em princípio, viabilizada a extradição. No mandado de segurança, arguiu, entretanto, que a perda da sua nacionalidade brasileira não poderia ter ocorrido, já que a nacionalidade americana havia sido requerida para que pudesse valer-se de direitos civis no país setentrional.

A Corte entendeu que, com o green card, a impetrante poderia trabalhar e morar nos EUA, concluindo que a naturalização não fora forçada, mas livremente requerida, no sentido que a Constituição liga à perda do vínculo jurídico com o Brasil. Dessa maneira, o processo extradicional poderia ter curso. Prevaleceu a tese de não ser necessário processo judicial para a perda da nacionalidade, o que somente se requer para a perda da naturalização de súdito 
estrangeiro que vem a desempenhar atividade nociva ao interesse nacional (art. 12, $\$ 4^{\circ}, \mathrm{I}, \mathrm{da} \mathrm{CF}$ ). $\mathrm{O}$ mandado de segurança foi indeferido.

\section{DIREITO À PRIVACIDADE, SIGILO BANCÁRIO E ACESSO DE DADOS PELO FISCO}

A Constituição brasileira não eleva explicitamente o sigilo bancário ao grau de direito fundamental, mas a jurisprudência entende que o interesse de reserva de informaçôes sobre o correntista ajusta-se ao conjunto de pretensões decorrentes do direito à privacidade. Não se duvida de que não se trata de um direito absoluto, podendo ceder a outros interesses de ordem constitucional. Admite-se que a lei fixe casos em que o sigilo é transferido para outro órgão de governo. A autorização judicial é também exceção à reserva de acesso à informação.

A Lei Complementar no 105/2001 impõe que as instituições financeiras compatilhem com a Receita Federal informações sigilosas, garantindo, por meio de providências de ordem procedimental e material, que não sejam franqueadas a terceiros. Para o Tribunal, a transferência de sigilo dos bancos para o Fisco, de modo não acessível a terceiros, não corresponderia a hipótese de quebra de sigilo bancário. A medida, ademais, seria justificada, por se tratar de instrumento para fiscalizar o cumprimento do dever fundamental dos cidadãos de pagar impostos. Seria uma maneira, ainda, de conferir realidade ao princípio constitucional da capacidade contributiva em matéria tributária.

É curioso notar que, em julgamento de 15.12.2010, no RE 389.808, o STF havia decidido precisamente o contrário - que a lei complementar não poderia ter prescindido da autorização judicial para os atos de compartilhamento dos mesmos dados. Naquela decisão, não se reuniu a maioria necessária para a declaração de inconstitucionalidade (seis ministros).

\section{LIBERDADE DE EXPRESSÃO E CLASSIFICAÇÃO DE PROGRAMAS DE TELEVISÃO SEGUNDO ADEQUAÇÃO A FAIXAS ETÁRIAS DISTINTAS}

A Constituição Federal confere à União a competência para classificar, segundo o seu conteúdo, diversões públicas e programas de rádio e TV. A atividade é exercida pelo Ministério da Justiça. O art. 21, XVI, da CF, refere que a classificação visa a "efeito indicativo». $\mathrm{O}$ art. 220 da Carta, na linha do art. $5^{\circ}$, IX, dispõe que:

A manifestação do pensamento, a criação, a expressão e a informação, sob qualquer forma, processo ou veículo não sofrerão qualquer restrição, observado o disposto nesta Constituição. 
Daí se deduz a liberdade fundamental de programação das emissoras de televisão.

Por outro lado, o art. 221, IV, da CF determina que essas programações atentem para o respeito devido aos valores éticos e sociais da pessoa e da família. A proteção da criança e do adolescente tem caráter impositivo para o Estado ditado pelo art. 227 do Diploma constitucional.

Ante essas coordenadas pôs-se ao STF a indagação sobre a validade de dispositivo do Estatuto da Criança e do Adolescente (artigo 254) que cominava sanção à emissora de TV que transmitisse espetáculo fora do horário autorizado pelo Ministério da Justiça. As punições partiam de multas e chegavam à suspensão dos serviços da emissora por dois dias.

O STF julgou inconstitucional a obrigação imposta de obedecer à classificação. Entendeu que, no confronto da liberdade de expressão com a necessidade de proteger os menores, o constituinte optou pelo sistema de classificação dos programas em caráter meramente indicativo. Com isso, os telespectadores recebem do Estado informação para que eles próprios decidam se permitirão que as crianças sob a sua guarda assistam ao espetáculo. A classificação, desse modo, é um aviso aos usuários, mas não se trata de uma autorização para que o programa seja veiculado, daí a inconstitucionalidade do dispositivo de lei que parte do suposto, contrário, de que o Ministerio da Justiça autoriza a exibição em determinados momentos do dia. O Poder Público pode recomendar que o programa seja exibido a partir de determinado horário, mas não lhe cabe determiná-lo.

\section{LIBERDADE DE EXPRESSÃO, TATUAGENS E POLICIAL}

No RE 898.450, o Supremo Tribunal Federal julgou, sob a sistemática da repercussão geral, em 17 de agosto de 2016, a validade de edital de concurso público para preenchimento de cargos de policial militar que barrava candidatos que possuíssem tatuagens no corpo, visíveis quando o portador estivesse de calção e camiseta.

O Tribunal considerou que a tatuagem é uma forma de exercício da liberdade de expressão garantida constitucionalmente. Apontou, também, que, se as tatuagens, no passado, identificavam grupos à margem da sociedade, há anos que teria perdido o estigma, não mais atraindo a conotação de contrariedade aos bons costumes e ao ordenamento jurídico. A Corte ressalvou, contudo, que algumas tatuagens podem ser causa de recusa do candidato, como as que incitem condutas contrárias aos postulados decorrentes do princípio da dignidade da pessoa, que estampem valores contrários ao desempenho da função pública pretendida ou que sejam obscenas. Lê-se no acórdão: 
As restrições estatais para o exercício de funções públicas originadas do uso de tatuagens devem ser excepcionais, na medida em que implicam uma interferência incisiva do Poder Público em direitos fundamentais diretamente relacionados ao modo como o ser humano desenvolve a sua personalidade.

A cláusula editalícia que cria condição ou requisito capaz de restringir o acesso a cargo, emprego ou função pública por candidatos possuidores de tatuagens, pinturas ou marcas, quaisquer que sejam suas extensões e localizações, visíveis ou não, desde que não representem símbolos ou inscrições alusivas a ideologias que exteriorizem valores excessivamente ofensivos à dignidade dos seres humanos, ao desempenho da função pública pretendida, incitação à violência iminente, ameaças reais ou representem obscenidades, é inconstitucional.

A tatuagem considerada obscena deve submeter-se ao Miller-Test, que, por seu turno, reclama três requisitos que repugnam essa forma de pigmentação, a saber: (i) o homem médio, seguindo padróes contemporâneos da comunidade, considere que a obra, tida como um todo, atrai o interesse lascivo; (ii) quando a obra retrata ou descreve, de modo ofensivo, conduta sexual, nos termos do que definido na legislação estadual aplicável, (iii) quando a obra, como um todo, não possua um sério valor literário, artístico, político ou científico.

A tatuagem que incite a prática de uma violência iminente pode impedir o desempenho de uma função pública quando ostentar a aptidão de provocar uma reação violenta imediata naquele que a visualiza, nos termos do que predica a doutrina norte-americana das "fighting words», como, v.g., "morte aos delinquentes».

\section{LIBERDADE RELIGIOSA E CRÍTICA A OUTRAS RELIGIÕES}

Um ministro de confissão religiosa publicou livro em que criticava religióes de origem africana como a umbanda e o candomblé. No RHC 134.682/ BA, a Primeira Turma, em 29.11.2016, analisou se a conduta caracterizava crime de racismo, como constava de denúcia deduzida contra o líder religioso.

O Supremo Tribunal teve a ocasião de assinalar que a liberdade religiosa, não obstante ser um direito fundamental, não é protegida de modo absoluto. Acentuou que, no seu núcleo, estão as liberdades de crença, consciência e culto, alcançando, além disso, o proselitismo, por meio do qual membros de algumas religiōes se dedicam a convencer pessoas a aderir à fé que professam. O proselitismo é também uma projeção específica da liberdade de expressão, e admiti-lo é consequência de a Constituição não propugnar uma mera indiferença ao fenômeno religioso.

O acórdão reconheceu que o proselitismo pode-se valer de uma hierarquização entre as religiōes. Isso não configura, por si só, preconceito vedado constitucionalmente, desde que o objetivo não seja o de eliminar um indivíduo ou um grupo apodado de inferior, mas o de ajudar os que não participam da fé a descobrir e aderir aos postulados apresentados, com vistas ao seu 
próprio bem. «O discurso proselitista, nessas hipóteses — acentuou o acórdão —, associa-se ao dever de auxílio a adeptos de outras religióes, vistas como equivocadas».

O proselitismo pode-se tornar impróprio, conforme a Corte advertiu, ao dizer que «descabe potencializar o proselitismo, por si, para fins de reconhecimento de realização de uma espécie de guerra santa, mantida com base em discurso odioso, tampouco para legitimar atos de violência ou de perseguição aptos a macular a dignidade humana».

No caso apreciado, o conteúdo do livro foi tido como incluído no proselitismo admitido pela liberdade de expressão religiosa, concedendo-se o habeas corpus.

\section{DIREITO DE PROPRIEDADE E PENA DE CONFISCO}

A Constituição, com a Emenda à Constituição no 81/2014, determina a perda da propriedade em que se cultivam plantas com potencial psicotrópico. Diz a norma:

As propriedades rurais e urbanas de qualquer região do País onde forem localizadas culturas ilegais de plantas psicotrópicas ou a exploração de trabalho escravo na forma da lei serão expropriadas e destinadas à reforma agrária e a programas de habitação popular, sem qualquer indenização ao proprietário e sem prejuízo de outras sançōes previstas em lei, observado, no que couber, o disposto no art. $5^{\circ}$.

No RE 635.336/PE, julgado em 14.12.2016, foi posto em debate saber se essa expropriação poderia prescindir de juízo de culpa do proprietário.

O Tribunal chamou a atenção para o fato de a Emenda n. 81/2014 ter estabelecido uma nova sistemática para a perda da propriedade, que, até então, era consequência automática da descoberta de culturas ilegais de plantas alucinógenas. Passou-se, em 2014, a exigir a observância, no que couber, do art. $5^{\circ}$ da Constituição, entre cujos incisos se assegura o direito de propriedade.

O Tribunal entendeu que a medida prevista é um confisco constitucional de caráter punitivo — «uma penalidade imposta ao proprietário que praticou a atividade ilícita de cultivar plantas psicotrópicas, sem autorização prévia do órgão sanitário do Ministério da Saúde». Salientou que a Constituição não exige que o proprietário da gleba tenha ele próprio participado do cultivo proibido, mas a referência ao art. $5^{\circ}$ da Carta permite concluir que deve $(\mathrm{e}$ basta) haver algum grau de culpa a ele imputável. O proprietário, assim, podese opor ao confisco, demonstrando que não agiu nem mesmo com culpa in vigilando ou in eligendo no evento. $\mathrm{O}$ acórdão exemplificou, dizendo caber ao proprietário da gleba demonstrar que foi esbulhado ou até enganado por 
possuidor ou detentor. $\mathrm{O}$ ônus da prova de fatores que excluam a culpa foi tido como recaindo sobre o proprietário das terras. Fixou-se a inteligência, então, de que «a expropriação revista no art. 243 da Constituição Federal pode ser afastada, desde que o proprietário comprove que não incorreu em culpa, ainda que in vigilando ou in eligendo».

\section{DIREITO À FILIAÇÃO E DIGNIDADE DA PESSOA}

No RE 898.060, julgado em 22 de setembro de 2016, o STF viu-se diante da questão de aferir se a paternidade sócio-afetiva exclui as consequências da paternidade biológica. Na demanda, a autora demonstrara, por meio de teste de DNA, que era filha biológica do recorrente, não obstante o seu registro civil apontasse como pai outro homem, que efetivamente cuidara dela por mais de 20 anos. Indagava-se se a autora poderia exigir os direitos típicos da filiação do pai biológico.

O Tribunal entendeu, invocando o princípio da dignidade humana e da paternidade responsável, que a autora fazia jus aos direitos decorrentes da filiação biológica, apesar da concomitância da filiação afetiva existente. Afirmou que, «atualmente, não cabe decidir entre a filiação afetiva e a biológica quando o melhor interesse do descendente é o reconhecimento jurídico de ambos os vínculos». Garantiram-se à autora os efeitos jurídicos de vínculo genético relativos ao nome, a pretensões de alimentos e à sucessão hereditária.

\section{INVIOLABILIDADE DE DOMICÍLIO}

No RE 603.616, publicado no DJe de 10 de maio de 2016, a Corte enfrentou o tema do controle judicial cabível quando há invasão de domicílio, nas hipóteses em que não se exige prévia autorização judicial.

$\mathrm{O}$ art. $5^{\circ}, \mathrm{XI}$, da Constituição, arrola como direito fundamental que a moradia não pode sofrer entrada por outrem, sem o consentimento do morador, exceto nas hipóteses que o constituinte enumera ao dispor:

A casa é asilo inviolável do indivíduo, ninguém nela podendo penetrar sem consentimento do morador, salvo em caso de flagrante delito ou desastre, ou para prestar socorro, ou, durante o dia, por determinação judicial.

A intervenção judicial não é mencionada no caso de flagrante delito. No recurso apreciado, o Tribunal assentou, porém, que também aí deve haver o controle judicial, embora exercido após a entrada no domicílio protegido. Disse a Corte que, «muito embora o flagrante delito legitime o ingresso forçado em casa sem determinação judicial, a medida deve ser controlada judicialmente», 
sob pena de se esvaziar o núcleo essencial da garantia. Explicou, ainda, que a justificativa a ser apresentada depois do ingresso dos agentes públicos na casa deve descrever situação que deixe claro que, antes do ingresso, havia fundada razão para crer que ali se desenvolvia atividade criminosa. Por isso, o acórdão mencionou que "não será a constatação de situação de flagrância, posterior ao ingresso, que justificará a medida». Vale dizer que a mera especulação de que pode estar sendo praticado crime numa casa não justifica a invasão, mesmo que, ao adentrá-la, acaso venha a ser encontranda situação delituosa. Esses são os parâmetros necessários para se entender a tese formulada, para fins de repercussão geral, vertida nestes termos:

A entrada forçada em domicílio sem mandado judicial só é lícita, mesmo em período noturno, quando amparada em fundadas razões, devidamente justificadas a posteriori, que indiquem que dentro da casa ocorre situação de flagrante delito, sob pena de responsabilidade disciplinar, civil e penal do agente ou da autoridade e de nulidade dos atos praticados.

\section{RESPONSABILIDADE CIVIL DO ESTADO POR MORTE DE PRESIDIÁRIO}

O Tribunal fixou tese sobre a responsabilidade civil do Estado pela morte de presidiário sob a sua guarda. A responsabilidade do Estado, aí, não vai ocorrer em qualquer circunstância, mas dependerá de o Estado não haver cumprido dever de resguardar o preso. A responsabilidade estará caracterizada se houver «dever legal e a efetiva possibilidade de agir para impedir o resultado danoso». A doutrina admitida para caracterizar a natureza da responsabilidade civil do Estado é a do chamado risco administrativo, quer para casos de ação, quer para as hipóteses de omissões geradoras de dano para o particular.

$\mathrm{Na}$ ementa do acórdão, as razões de decidir da Corte estão bem resumidas. Lê-se ali:

O dever constitucional de proteção ao detento somente se considera violado quando possível a atuação estatal no sentido de garantir os seus direitos fundamentais, pressuposto inafastável para a configuração da responsabilidade civil objetiva estatal, na forma do artigo 37, $\$ 6^{\circ}$, da Constituição Federal. 5. Ad impossibilia nemo tenetur, por isso que nos casos em que não é possível ao Estado agir para evitar a morte do detento (que ocorreria mesmo que o preso estivesse em liberdade), rompe-se o nexo de causalidade, afastando-se a responsabilidade do Poder Público, sob pena de adotar-se contra legem e a opinio doctorum a teoria do risco integral, ao arrepio do texto constitucional. 
A morte do detento pode ocorrer por várias causas, como, v. g., homicídio, suicídio, acidente ou morte natural, sendo que nem sempre será possível ao Estado evitá-la, por mais que adote as precauçôes exigíveis. A responsabilidade civil estatal resta conjurada nas hipóteses em que o Poder Público comprova causa impeditiva da sua atuação protetiva do detento, rompendo o nexo de causalidade da sua omissão com o resultado danoso.

Foi formulada a tese de que «em caso de inobservância do seu dever específico de proteção previsto no artigo $5^{\circ}$, inciso XLIX, da Constituição Federal, o Estado é responsável pela morte do detento».

\section{SEPARAÇÃO DE PODERES E DEFENSORIA PÚBLICA}

A Defensoria Pública é a instituição que o constituinte criou para garantir o acesso dos que não tem recursos financeiros ao Judiciário, sendo instrumento de primordial importância para a efetivação dos direitos fundamentais dos hipossuficientes. Desde de 1988, o prestígio crescente da instituição tem levado a reformas da Constituição, tendentes a conferir especial autonomia ao órgão que se situa na estrutura do Poder Executivo.

Em 2004, a Emenda à Constituição no 45 conferiu às Defensorias Públicas estaduais a autonomia funcional e administrativa além da prerrogativa da iniciativa de proposta orçamentária para a elaboração das leis orçamentárias anuais. A emenda não cogitou da Defensoria Pública da União, que atua perante a Justiça Federal e que não se confunde com as Defensorias Públicas de cada Estado-membro. Por iniciativa de parlamentares, foi, então, proposta outra emenda à Carta, para que a regra da EC 45 também aproveite ao órgão federal. A proposta vingou e o Texto constitucional passou a ostentar um $₫ 3^{\circ}$ no seu art. 134, estipulando a extensão desejada.

A Presidente da República, porém, ajuizou ação direta de inconstitucionalidade, arguindo a invalidade da norma, porque a iniciativa da proposta não havia sido sua. $\mathrm{O}$ argumento é tributario da circunstância de a Constituição estabelecer que projetos de lei que disciplinem órgãos do Executivo e disponham sobre regime jurídico de servidores públicos somente podem ser debatidos no Congresso Nacional se o Presidente da República encaminhar à Câmara dos Deputados proposição normativa a respeito.

O Tribunal, na ADI MC 5296, julgada em 18 de maio, assentou que, no campo das propostas de emendas à Constituição Federal, não se aplicam os casos de reserva de iniciativa de lei, não havendo, em consequência, ofensa ao modelo de separação de poderes adotado. 
É interessante notar que a Corte não abonou a possibilidade de se conferir, por meio de emenda à Carta, autonomia a qualquer entidade do Executivo; considerou, antes, que a relevância da Defensoria Pública autorizava o alvitre do constituinte de reforma. Ressaltou que a Defensoria Pública tem como parte antagônica no processo penal o Ministério Público, que possui grau elevado de autonomia. Além disso, a Defensoria Pública da União, nas causas cíveis, se bate sobretudo contra a própria União, o que demonstraria a importância de se assegurar a sua independência institucional.

Uma vez que as Defensorias Públicas gozam de autonomia admistrativa e financeira (da mesma forma que o Poder Judiciário, nos termos do art. 99 da CF), cabe-lhes a tomada das decisões administrativas de gestão de recursos e de pessoal, sem a interferência do Chefe do Executivo. Na ADI 5286, julgada em 18 de maio, a Corte afirmou a inconstitucionalidade de norma estadual que apontava o Governador como autoridade nomeante de cargos de chefia na estrutura burocrática da Defensoria Pública do Estado. O Defensor Público-geral é nomeado pelo Governador, mas a definição dos que ocuparão cargos de chefia no órgão é exclusiva do Chefe da instituição.

No mesmo precedente, e à conta da autonomia financeira da Defensoria Pública, afirmou-se inconstitucional que o Governador reduzisse, no projeto de lei orçamentária anual, o montante indicado em proposta orçamentária elaborada pela Defensoria. Cabe à Assembleia Legislativa, querendo, abater as verbas projetadas, mas o Chefe do Executivo não pode recusar-se a juntar ao seu projeto de lei a proposta da Defensoria — da mesma forma que não o pode fazer com relação às propostas do Judiciário e do Ministério Público.

A participação da Defensoria Pública também é essencial para a discussão de projeto de lei de diretrizes orçamentárias, que fixa balizas para a lei orçamentária anual. Isso o que foi decidido na ADI MC 5.381, julgada na mesma sessão de 18 de maio.

\section{VAQUEJADA E VETO A TRATAMENTO CRUEL DE ANIMAIS}

A decisão do STF na ADI 4.983, julgada em 6 de outubro de 2016, motivou reações populares de indignação e até mesmo mobilização de protesto nas ruas de Brasília, reunindo, segundo a imprensa, 3 mil pessoas, com 410 caminhões, 1,2 mil cavalos, 53 ônibus e 114 carros $^{9}$. A decisão, ainda, motivou pronto início de processo legislativo com mira na produção de emenda à Constituição que superasse o entendimento fixado pela Corte.

9 cf. G1 em 25/10/2016. 
O Tribunal fora convocado a aferir a constitucionalidade de lei de um Estado do Norte do Brasil, em que se praticava a vaquejada. A lei dispunha sobre medidas de segurança para que o espetáculo fosse legítimo. O STF declarou a inconstitucionalidade da vaquejada, ela própria, no pressuposto de que não haveria meio de conciliá-la com a ordem constitucional.

A vaquejada é um evento de considerável popularidade nos meios rurais de diversos Estados da Federação. Consiste num desafio a que dupla de vaqueiros, montados em cavalos, consiga derrubar ao chão um boi que é, antes, subitamente solto, em disparada, numa arena. Os cavaleiros devem mostrar destreza e conseguir o objetivo, mediante puxões ao rabo do bovino. O feito exige destreza do cavaleiro e grande público é atraído para o festejo. O espetáculo é mais do que centenário e, em sua defesa, foi arguido que se trata de uma importante expressão do patrimônio cultural regional brasileiro.

No curso da demanda apurou-se que o boi sofre danos que caracterizam tratamento cruel. Foi exposto que:

(1) Os animais são enclausurados antes do momento em que são lancados à pista e, enquanto aguardam, são açoitados e instigados para que possam sair em disparada após aberto o portão do 'brete'; (2) os cavalos utilizados pelos vaqueiros podem sofrer um conjunto de lesōes decorrentes do esforço físico dispensado na corrida atrás do boi;

e, por fim (3), os gestos bruscos de tracionar e torcer a cauda do boi, bem como seu tombamento, podem acarretar sérias lesões aos animais.

O acórdão também aludiu a relatos de introdução de pimenta e mostarda no ânus do animal, além de choques elétricos, logo antes de lhe ser aberta a porta para arena, a fim de impulsionar-lhe a corrida

A prática foi tida como hostil ao art. 225, VII, da Constituição, que veda práticas que submetam os animais a crueldade. Em outras oportunidades o mesmo dispositivo foi causa para que se proibissem as chamadas brigas de galo e festejos sob a denominação de "farra do boi».

Uma parte do Plenário, porém, apontou que, no caso da vaquejada, havia que ser considerado que se estava diante de uma manifestação cultural. Como tal, tinha por si o art. 215 e seu $\$ 1^{\circ}$ da Constituição. Nesses dispositivos, está estabelecido que o Estado há de garantir a todos o pleno exercício dos direitos culturais e há de apoiar as manifestaçōes culturais, além de proteger as manifestações das culturas populares. A discussão passou a se travar sob o esquadro da ponderação entre o valor do meio ambiente e o da proteção da cultura popular.

A maioria formada estimou que o conflito surgido entre essas normas deveria ser resolvido conferindo-se maior peso ao meio ambiente, em comparação 
com o direito à manifestação cultural. A ação direta foi julgada procedente, dando-se por inconstitucional a prática da vaquejada.

$\mathrm{O}$ julgado merece dois registros. $\mathrm{O}$ primeiro deles, para realçar o fenômeno do diálogo da jurisdição constitucional com o parlamento que o acórdão ensejou. Pressões populares conduziram a que, logo em seguida ao julgamento, fosse iniciado processo de deliberação de proposta de emenda à Constituição que superasse o entendimento da Corte. De modo surpreendentente rápido, em junho de 2017 foi promulgada a Emenda à Constituição no 96, que acrescentou ao art. $225 \mathrm{um} \$ 7^{\circ}$, com estes dizeres:

Para fins do disposto na parte final do inciso VII do $₫ 1^{\circ}$ deste artigo, não se consideram cruéis as práticas desportivas que utilizem animais, desde que sejam manifestaçôes culturais, conforme o $\$ 1^{\circ}$ do art. 215 desta Constituição Federal, registradas como bem de natureza imaterial integrante do patrimônio cultural brasileiro, devendo ser regulamentadas por lei específica que assegure o bem-estar dos animais envolvidos.

É de se esperar que o Tribunal volte a ser provocado para examinar a inovação.

Num outro sentido, o acórdão revela uma propensão a se enxergar caso de ponderação entre princípios constitucionais, mesmo em hipótese que teria imediata solução pela direta aplicação de regras do Diploma constitucional. $\mathrm{Na}$ realidade, a circunstância de a vaquejada ser uma atividade com traços de manifestação cultural não era relevante para a aplicação do direito. O princípio do apoio a expressões culturais não tinha por que ser confrontado com a norma que proíbe o tratamento cruel a animais. Este último preceito tem a natureza de regra, e não a de um princípio a ser ponderado. De fato, a crueldade proibida não tem como ser graduada conforme as possibilidade jurídicas e fáticas - ou ela é respeitada ou é infringida. $\mathrm{O}$ veto expresso do constituinte traduz típica regra, que não tem como ser afastada pela invocação de um princípio amplo preconizando o maior suporte estatal possível para manifestaçōes culturais.

$\mathrm{Na}$ realidade toda a questão se resumia a apurar se a vaquejada configura prática cruel contra os animais que dela participam. Respondida esta indagação, a incidência do veto somente poderia ser afastada por outra regra que $\mathrm{o}$ excepcionasse concretamente $-\mathrm{o}$ que o Congresso Nacional buscou com a Emenda à Constituição no 96/2017. Nesse sentido o voto do relator, resumido na ementa do acórdão, ${ }^{10}$ é mais preciso- afasta a necessidade de um

10 «A obrigação de o Estado garantir a todos o pleno exercício de direitos culturais, incentivando a valorização e a difusão das manifestações, não prescinde da observância 
cotejo do tratamento cruel com a obrigação de o Poder Público dar suporte a práticas culturais, para simplesmente asserir que esse último dever não existe se a regra proibitiva do tratamento cruel tem incidência.

\section{CONCLUSÃO}

O ano de 2016 foi de intenso chamamento do Supremo Tribunal Federal ao palco dos eventos políticos. O Tribunal não se recusou a superar eventuais dificuldades técnicas para responder à necessidade de que deliberaçóes potencialmente traumáticas dos poderes políticos fossem tomadas de modo formalmente idôneo e respeitoso aos direitos fundamentais dos envolvidos. A crise político-econômica sem precedente que abateu o país decerto que influiu também nas revisões de jurisprudência levadas a efeito no âmbito de proteção de garantias constitucionais. O certo é que o Tribunal buscou estabelecer pontos de equilíbrio em instantes particularmente tumultuados - o êxito desse intento ainda é cedo para aquilatar.

do disposto no inciso VII do artigo 225 da Carta Federal, o qual veda prática que acabe por submeter os animais à crueldade. Discrepa da norma constitucional a denominada vaquejada». 